\title{
Land of the Permanent Wave
}




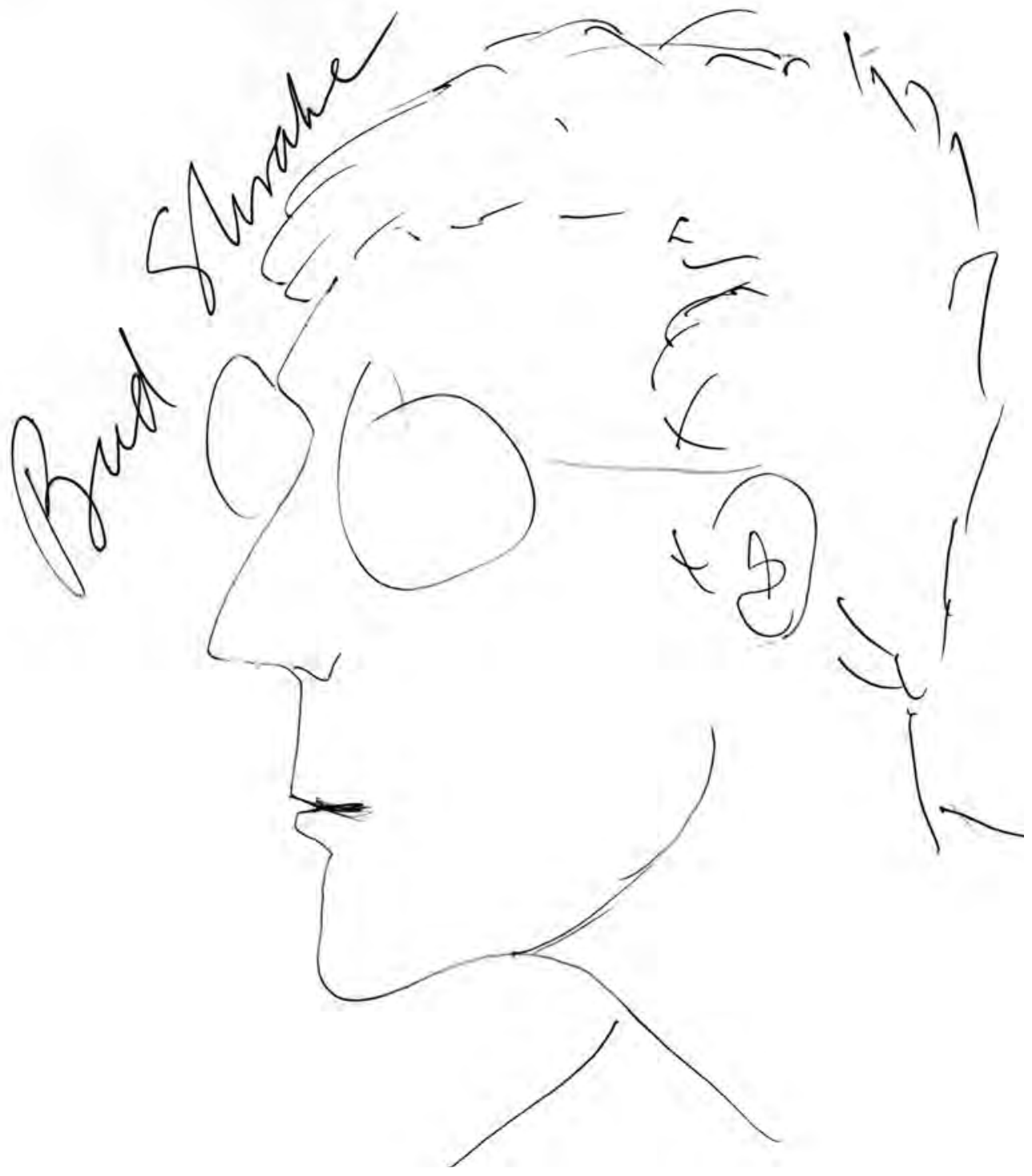

Southwestern Writers Collection Series CONNIE TODD, Editor 


\section{Land of the Permanent Wave \\ An \\ Edwin "Bud" \\ Shrake \\ Reader}

Edited and with an introduction by STEVEN L. DAVIS

Foreword by LARRY L. KING

$\checkmark$ UNIVERSITY OF TEXAS PRESS, AUSTIN 
Foreword copyright $\odot$ by Larry L. King

Copyright $\odot 2008$ by Edwin Shrake

All rights reserved

Printed in the United States of America

First edition, 2008

Requests for permission to reproduce material

from this work should be sent to:

Permissions

University of Texas Press

P.O. Box 7819

Austin, TX 78713-7819

www.utexas.edu/utpress/about/bpermission.html

( The paper used in this book meets the minimum requirements of ANSI/NISO Z39.48-1992 (R1997) (Permanence of Paper).

Library of Congress Cataloging-in-Publication Data

Shrake, Edwin.

Land of the permanent wave : an Edwin "Bud" Shrake reader / edited and with an introduction by Steven L. Davis ; foreword by Larry L. King. - 1st ed.

p. $\quad$ cm. - (Southwestern writers collection series)

ISBN 978-0-292-71804-3 (cl.: alk. paper)

I. Davis, Steven L. II. Title.

PS3569.H735A6 2008

$813 \cdot 54-\mathrm{dc} 22$

2007045365

The Southwestern Writers Collection Series originates from the Southwestern Writers Collection, an archive and literary center established at Texas State University-San Marcos to celebrate the region's writers and literary heritage. 
For Jody Gent-Bud Shrake

Para mis tres hermanos:

Jeff, Joe, Don-Steven L. Davis 
THIS PAGE INTENTIONALLY LEFT BLANK 